\title{
PANGAN HALAL DAN CARA MEMILIH PRODUK KEMASAN YANG AMAN DAN HALAL
}

\author{
Hermiza Mardesci, S.TP., MP \\ Dosen Teknologi Pangan Faperta UNISI \\ mimzaaci@yahoo.co.id
}

\begin{abstract}
Abstrak
Jaminan pangan halal dan keamanan pangan sangat dibutuhkan oleh konsumen. Oleh sebab itu, pengetahuan mengenai pangan halal dan keamanan pangan perlu ditingkatkan. Pangan yang baik dapat diartikan sebagai pangan yang memiliki cita rasa baik, sanitasi higine baik dan kandungan gizinya yang baik. Konsumsi makanan halal merupakan kewajiban bagi setiap Muslim. Ketentuan halal dan haramnya suatu bahan pangan berasal dari Allah SWT. Ketentuan ini tercantum di dalam Al-Quran dan Hadis.
\end{abstract}

\section{PENDAHULUAN}

Pangan halal merupakan isu yang cukup menarik untuk dikaji dan diperbincangkan. Hal ini dikarenakan semakin pesatnya perkembangan teknologi pangan terutama agroindustri pangan olahan yang mengakibatkan penggunaan ingredient dalam pengolahan pangan menjadi sangat bervariasi. Perkembangan penggunaan ingredient ini didorong oleh kebutuhan akan ingredient dengan sifat-sifat tertentu yang diinginkan dengan harga yang murah. Masalah yang kemudian timbul adalah banyaknya ingredient pangan baik bahan baku utama maupun bahan aditifnya yang sulit ditentukan kehalalan asal bahan pembuatnya. Padahal, kejelasan suatu informasi suatu produk pangan sangat penting agar konsumen mengetahui produk yang dikonsumsi tersebut adalah produk yang halal atau tidak jelas ketentuan hukumnya (Apriyantono, 2005).

Disamping itu, dalam Al Quran yang merupakan pedoman utama umat islam, Allah telah memberikan rambu- rambu yang jelas tentang perintah makanan. Sebagaimana firman Allah dalam surat Al Baqarah 168, "Hai manusia, makanlah segala sesuatu yang ada di bumi ini yang halal dan baik dan jangan kamu mengikuti jejak setan karena sesungguhnya setan itu musuh yang nyata bagimu". Serta di dalam Surat Al-Maidah ayat 88 Allah SWT menyatakan bahwa "Dan makanlah makanan yang halal lagi baik dari apa yang Allah telah rezekikan kepadamu, dan bertakwalah kepada Allah yang kamu beriman kepada-Nya". Hal ini mengungkapkan bahwa seseorang hendaknya mengkonsumsi makanan yang halal serta baik kandungan gizinya.

\section{PANGAN HALAL}

Pangan di dalam UU RI No. 7 Tahun 1996 Tentang Pangan didefinisikan sebagai segala sesuatu yang berasal dari sumber daya hayati dan air, baik yang diolah maupun yang tidak diolah yang diperuntukkan sebagai makanan atau minuman bagi konsumsi manusia, termasuk bahan tambahan 
pangan, bahan baku pangan, dan bahan lain yang digunakan dalam proses persiapan, pengolahan, dan atau pembuatan makanan dan minuman.

Dalam khasanah ilmu (tsaqafah) Islam, hukum asal segala sesuatu (benda) yang diciptakan Allah adalah halal dan mubah. Tidak ada satu pun yang haram, kecuali ada keterangan yang sah dan tegas tentang keharaman bahan tersebut. Hal ini berbeda dengan kaidah perbuatan yang menuntut setiap apapun yang dilakukan manusia dalam hal ini seorang muslim harus terikat dengan hukum syara' (wajib, sunah, mubah/boleh, makruh, haram). Sebagaimana kaidah fiqh yang menyatakan "Hukum asal bagi setiap benda/barang adalah mubah, selama tidak ada dalil yang mengharamkannya" dan "Hukum asal bagi perbuatan manusia/muslim adalah terikat dengan hukum syara'Islam" (An-nabani,2001). Kedua kaidah tersebut menyatakan bahwa hukum asal dari benda adalah halal jika tidak ada dalil yang dengan tegas mengharamkannya dan hukum asal dari perbuatan adalah terikat dengan aturan Islam.

Halal berarti boleh, sedangkan haram berarti tidak boleh (Qardhawi, 2000). Selain masalah halal dalam perilaku yang menjadi standar minimal perilaku seorang muslim, Allah SWT juga mengatur halal dalam masalah makanan maupun minuman. Di dalam Qur'an Surat Al-Maidah ayat 3, Allah SWT berfirman bahwa "Telah diharamkan atas kamu bangkai, darah, daging babi, binatang yang disembelih bukan karena Allah, yang (mati) karena dicekik, yang (mati) karena dipukul, yang (mati) karena jatuh dari atas, yang (mati) karena ditanduk, yang (mati) karena dimakan oleh binatang buas, kecuali yang dapat kamu sembelih dan yang disembelih untuk berhala".

Pangan yang halal adalah pangan yang diizinkan untuk dikonsumsi atau tidak terikat dengan ketentuan-ketentuan yang melarangnya. Atau diartikan sebagai segala sesuatu yang bebas dari bahaya duniawi dan ukhrawi (Girindra 2005). Dalam hal ini, pangan yang baik dapat diartikan sebagai pangan yang memiliki cita rasa baik, sanitasi higine baik dan kandungan gizinya yang baik. Konsumsi makanan halal merupakan kewajiban bagi setiap Muslim. Ketentuan halal dan haramnya suatu bahan pangan berasal dari Allah SWT. Ketentuan ini tercantum di dalam AlQuran dan Hadis.

Menurut Apriyantono (2001), kriteria makanan atau minuman halal diantaranya :

1. Tidak boleh mengandung sesuatu yang dianggap haram menurut hukum Islam.

2. Pada tahap persiapan, proses, transportasi, dan penyimpanan menggunakan peralatan yang bebas dari sesuatu yang dianggap haram menurut hukum Islam.

3. Pada tahap persiapan, proses, transportasi, dan penyimpanan tidak terjadi kontak langsung dengan makanan yang haram menurut hukum Islam.

\section{SISTEM JAMINAN HALAL}

Sistem Jaminan Halal (SJH) adalah suatu perangkat kerja yang tersusun dari komitmen manajemen, sumber daya, dan prosedur yang saling berhubungan untuk menjamin kehalalan produk sesuai dengan persyaratan sehingga status kehalalannya konsisten dan berkelanjutan (LPPOM MUI 2010a). Sistem Jaminan Halal dapat mengadopsi prinsip-prinsip sistem manajemen yang 
telah dikembangkan sebelumnya seperti Total Quality Management (TQM), ISO 9000, dan Hazard Analysis Critical Control Point (HACCP) (Apriyantono et al. 2007).

Pengembangan sistem jaminan halal didasarkan pada konsep total quality management yang terdiri atas empat unsur utama yaitu komitmen, kebutuhan konsumen, peningkatan tanpa penambahan biaya, dan menghasilkan barang setiap waktu tanpa rework, tanpa reject, tetap inspection. Karena itu dalam prakteknya, penerapan sistem jaminan halal dapat dirumuskan untuk menghasilkan suatu sistem yang ideal, yaitu zero limit, zero defect, dan zero risk (three zero consept). Artinya material haram tidak boleh ada pada level apapun (zero limit), tidak memproduksi produk haram (zero defect), dan tidak ada resiko merugikan yang diambil bila mengimplementasikan sistem ini (zero risk).

Total Quality Management didefinisikan sebagai sebuah sistem yang mengharuskan setiap orang di dalam setiap posisi dalam organisasi mempraktekan dan berpartisipasi dalam manajemen halal dan aktivitas peningkatan produktivitas. Manajemen halal bermula dan berakhir dengan pendidikan yang kontinyu (Apriyantono 2001).

Sistem jaminan halal merupakan kerangka kerja yang dipantau terus menerus dan dikaji secara periodik untuk memberikan arahan yang efektif bagi pelaksanaan kegiatan proses produksi halal. Sistem Jaminan Halal harus diuraikan scara tertulis dalam bentuk Manual Halal yang secara garis besar terdiri dari :

1. Pernyataan kebijakan perusahaan tentang halal (halal policy)

2. Panduan halal (halal guidelines)
3. Sistem Manajemen Halal (halal management system)

4. Uraian titik kritis keharaman produk (haram critical control point)

5. Sistem Audit Halal Internal (internal halal audit system)

\section{SERTIFIKASI HALAL}

Sertifikasi halal merupakan pemeriksaan yang rinci terhadap suatu produk yang selanjutnya diputuskan dalam bentuk fatwa MUI. Sertifikasi halal bertujuan untuk memberikan kepastian kehalalan suatu produk berupa sertifikat halal, sehingga dapat menentramkan batin yang mengonsumsinya. Selain itu bagi produsen, sertifikasi halal dapat mencegah kesimpangsiuran status kehalalan produk yang dihasilkan. Sertifikat halal adalah bukti sah tertulis yang menyatakan kehalalan suatu produk yang dikeluarkan olah MUI atas dasar fatwa yang ditetapkan oleh Komisi Fatwa MUI (Girindra 2008).

Lembaga yang berwenang melakukan sertifikasi halal di Indonesia yaitu LPPOM MUI. Sertifikasi dan pencantuman tanda halal bersifat sukarela (tidak ada keharusan). Namun, hal ini perlu dilakukan mengingat kehalalan suatu produk untuk dikonsumsi oleh umat Islam hukumnya wajib. Sementara itu, kehalalan suatu produk dapat menjamin bahwa produk tesebut diolah dengan baik dan aman dikonsumsi bagi siapa pun. Bagi produsen sendiri, produk bersertifikat halal dapat membuka peluang ekspor yang luas karena produknya memiliki keunggulan kompetitif dibandingkan dengan industri pangan lainnya.

Sebelum produsen mengajukan Sertifikat Halal bagi produknya, maka terlebih dahulu disyaratkan yang 
bersangkutan menyiapkan hal-hal sebagai berikut:

1. Produsen menyiapkan suatu Sistem Jaminan Halal (Halal Assurance System).

2. Sistem Jaminan Halal tersebut harus didokumentasikan secara jelas dan rinci serta merupakan bagian dari kebijakan manajemen perusahaan.

3. Dalam pelaksanaannya, Sistem Jaminan Halal ini diuraikan dalam bentuk panduan halal (Halal Manual). Tujuan membuat panduan halal adalah untuk memberikan uraian sistem manajemen halal yang dijalankan produsen. Selain itu, panduan halal ini dapat berfungsi sebagai rujukan tetap dalam melaksanakan dan memelihara kehalalan produk tersebut.

4. Produsen menyiapkan prosedur baku pelaksanaan (Standard Operating Prosedure) untuk mengawasi setiap proses yang kritis agar kehalalan produknya dapat terjamin.

5. Baik panduan halal maupun prosedur baku pelaksanaan yang disiapkan harus disosialisasikan dan diuji coba di lingkungan produsen, sehingga seluruh jajaran dari mulai direksi sampai karyawan memahami tata cara memproduksi produk halal dan baik.

6. Produsen melakukan pemeriksaan intern (audit internal) serta mengevaluasi keseuaian Sistem Jaminan Halal yang dilakukan untuk menjamin kehalalan produk.

7. Perusahaan harus mengangkat minimum seorang Auditor Halal Internal yang beragama Islam dan berasal dari bagian yang terkait dengan produksi halal.

\section{TAHAPAN PROSES SERTIFIKASI HALAL}

Secara umum proses sertifikasi halal dibagi dalam beberapa tahapan, yaitu: (1) persiapan pengajuan sertifikasi halal, (2) pendaftaran sertifikasi halal, (3) audit Sistem Jaminan Halal, (3) audit di lokasi pabrik, (4) evaluasi rapat auditor, dan (5) penentuan kehalalan oleh Sidang Fatwa MUI.

a. Pendaftaran sertifikasi halal dapat dilakukan di tiga tempat, yaitu (1) BPOM, (2) LPPOM MUI Pusat, dan (3) LPPOM MUI Provinsi. Pendaftaran melalui BPOM dilakukan untuk produk yang membutuhkan pencantuman label halal pada kemasannya dan dijual secara langsung untuk konsumsi masyarakat (industri pengolahan yang menghasilkan produk retail). Pendaftaran melalui LPPOM MUI Pusat dilakukan untuk industri pengolahan dan restoran yang memiliki jangkauan pemasaran atau outlet lebih dari satu provinsi. Sementara itu, pendaftaran melalui LPPOM MUI Daerah dilakukan untuk industri pengolahan yang termasuk dalam kelompok Air Minum Dalam Kemasan (AMDK), bleaching earth, dan karbon aktif. Serta, restoran atau katering atau Rumah Potong Hewan (RPH) yang memiliki jangkauan pemasaran atau outlet hanya pada provinsi tersebut (pemasaran bersifat lokal) di daerahnya.

b. Setiap produsen yang mengajukan permohonan Sertifikat Halal bagi produknya, harus mengisi borang yang telah disediakan. Borang tersebut berisi informasi tentang data perusahaan, jenis dan nama produk serta bahan-bahan yang digunakan. 
c. Borang yang sudah diisi beserta dokumen pendukungnya dikembalikan ke sekretariat LPPOM MUI untuk diperiksa kelengkapannya, dan bila belum memadai perusahaan harus melengkapi sesuai dengan ketentuan.

d. LPPOM MUI akan memberitahukan perusahaan mengenai jadwal audit. Tim Auditor LPPOM MUI akan melakukan pemeriksaan atau audit ke lokasi produsen. Pada saat audit, perusahaan harus dalam keadaan memproduksi produk yang disertifikasi.

e. Hasil pemeriksaan atau audit dan hasil laboratorium (bila diperlukan) dievaluasi dalam Rapat Auditor LPPOM MUI. Hasil audit yang belum memenuhi persyaratan diberitahukan kepada perusahaan melalui audit memorandum. Jika telah memenuhi persyaratan, auditor akan membuat laporan hasil audit guna diajukan pada Sidang Komisi Fatwa MUI untuk diputuskan status kehalalannya.

f. Laporan hasil audit disampaikan oleh Pengurus LPPOM MUI dalam Sidang Komisi Fatwa MUI pada waktu yang telah ditentukan.

g. Sidang Komisi Fatwa MUI dapat menolak laporan hasil audit jika dianggap belum memenuhi semua persyaratan yang telah ditentukan, dan hasilnya akan disampaikan kepada produsen pemohon sertifikasi halal.

h. Sertifikat Halal dikeluarkan oleh Majelis Ulama Indonesia setelah ditetapkan status kehalalannya dan status implementasi SJH oleh Komisi Fatwa MUI.

i. Sertifikat Halal dan Status Implementasi SJH berlaku selama dua tahun sejak tanggal penetapan fatwa. j. Tiga bulan sebelum masa berlaku Sertifikat Halal berakhir, produsen harus mengajukan perpanjangan sertifikat halal sesuai dengan aturan yang telah ditetapkan LPPOM MUI.

Apabila produsen telah mendapatkan sertifikat halal, maka perlu diperhatikan juga untuk masa berlaku, sistem pengawasan, dan prosedur perpanjangan sertifikat halal tersebut. Hal-hal yang perlu diketahui untuk masa berlaku sertifikat halal, diantaranya :

1. Sertifikat Halal hanya berlaku selama dua tahun dan Surat Keterangan Halal diberikan untuk setiap pengapalan untuk daging yang diekspor.

2. Tiga bulan sebelum berakhir masa berlakunya sertifikat, LPPOM MUI akan mengirimkan surat pemberitahuan kepada produsen yang bersangkutan.

3. Dua bulan sebelum berakhir masa berlakunya sertifikat, produsen harus mendaftar kembali untuk Sertifikat Halal yang baru.

4. Produsen yang tidak memperbaharui Sertifikat Halal, maka tidak diizinkan lagi menggunakan Sertifikat Halal tersebut dan dihapus dari daftar yang terdapat dalam majalah resmi LPPOM MUI, Jurnal Halal.

5. Jika Sertifikat Halal hilang, pemegang harus segera melaporkannya ke LPPOM MUI.

6. Sertifikat Halal yang dikeluarkan oleh MUI adalah milik MUI. Oleh sebab itu, jika karena sesuatu hal diminta kembali oleh MUI, maka pemegang sertifikat wajib menyerahkannya.

7. Keputusan MUI yang didasarkan atas fatwa MUI tidak dapat diganggu gugat. 


\section{HUKUM TENTANG PANGAN HALAL}

Dalam PP No. 69 tahun 1999 pasal 1, pangan halal adalah pangan yang tidak mengandung unsur atau bahan yang haram atau dilarang untuk dikonsumsi umat Islam, baik menyangkut bahan baku pangan, bahan bantu dan bahan penolong lainnya termasuk bahan pangan yang diolah melalui proses rekayasa genetika dan irradiasi pangan dan pengelolaannya dilakukan sesuai dengan ketentuan hukum agama Islam. Makanan yang halal adalah semua jenis makanan yang tidak mengandung unsur atau bahan yang terlarang/haram dan atau diolah/diproses menurut agama Islam (Keputusan bersama Menkes dan Menag No. 427/me.kes/VIII/1985 dan No. 68 tahun 1985 pasal 1).

Perkembangan peraturan perundang-undangan terkait pangan halal diIndonesia adalah sebagai berikut :

1. Peraturan Menteri Kesehatan RI No. 280/Menkes/Per/XI/1976 tentang Ketentuan Peredaran dan Penandaan pada Makanan yang mengandung Bahan berasal dari Babi.

Pasal 2 :

1) Pada wadah atau bungkus makanan yang diproduksi di dalam negeri maupun yang berasal dari impor yang mengandung bahan yang berasal dari babi harus dicantumkan tanda peringatan.

2) Tanda peringatan tersebut yang dimaksud pada ayat (1) harus berupa gambar babi dan tulisan yang berbunyi : MENGANDUNG BABI" dan harus ditulis dengan huruf besar berwarna merah dengan ukuran sekurangkurangnya Universe Medium Corps 12, di dalam garis kotak persegi yang juga berwarna merah.

2. Permenkes RI No. 76/Menkes/Per/III/78 tentang label dan Periklanan Makanan, pasal 2 menyatakan bahwa : Kalimat, katakata, tanda lambang, logo, gambar dan sebagainya yang terdapat pada label atau iklan harus sesuai dengan asal, sifat, komposisi, mutu dan kegunaan makanan.

3. Surat Keputusan Bersama antara Menteri Agama dan Menteri Kesehatan No. 427/Menkes/SKB/ VIII/1985 dan No. 68/1985 tentang Pencantuman Tulisan "Halal" pada Label Makanan.

Pasal 1 : Tulisan "halal" adalah tulisan yang dicantumkan pada label/penandaan yang memberikan jaminan tentang halalnya makanan tersebut bagi pemeluk agama Islam

Pasal 2 : Produsen yang mencantumkan tulisan "halal" pada label atau penandaan makanan produknya bertanggungjawab terhadap halalnya makanan tersebut bagi pemeluk agama Islam.

Pasal 4 :

1) Pengawasan preventif terhadap ketentuan pasal 2

Keputusan Bersama ini dilakukan oleh Tim Penilaian Pendaftaran Makanan Departemen Kesehatan RI, cq. Direktorat Jenderal Pengawasan Obat dan Makanan.

2) Dalam tim penilaian pendaftaran makanan sebagaimana dimaksud pada ayat (1) pasal ini, diikutsertakan unsur Departemen Agama RI.

3) Pengawasan di lapangan terhadap pelaksanaan ketentuan pasal 2 
Keputusan Bersama ini dilakukan oleh aparat Departemen Kesehatan RI.

4. UU No. 23 tahun 1992 tentang Kesehatan, pasal 214 ayat (2) penjelasan butir (d) : Ketentuan lainnya misalnya pencantuman kata atau tanda halal yang menjamin bahwa makanan dan minuman yang dimaksud diproduksi dan diproses sesuai dengan persyaratan makanan.

5. UU No. 7 tahun 1996 tentang Pangan, pasal (34) ayat (1) : Setiap orang yang menyatakan dalam label atau iklan bahwa pangan yang diperdagangkan adalah sesuai dengan persyaratan agama atau kepercayaan tertentu bertanggung jawab atas kebenaran peryataan berdasarkan persyaratan agama atau kepercayaan tersebut. Penjelasan pasal 34 ayat (1) : Dalam ketentuan ini benar tidaknya suatu pernyataan halal dalam label atau iklan pangan tidak hanya dapat dari segi bahan baku pangan, bahan tambahan pangan, atau bahan bantu lainnya yang digunakan dalam memproduksi pangan, tetapi mencakup pula proses pembuatannya

6. Keputusan Menkes RI No. 82/Menkes/SK/I/1996 tentang Pencantuman Tulisan Halal pada Label Makanan dan perubahannya berupa Keputusan Menteri Kesehatan RI No. 924/Menkes/SK/VII/1996, beserta peraturan pelaksanaannya berupa Keputusan Dirjen POM No. HK. 00.06.3.00568 tentang Tata Cara Pencantuman Tulisan Halal pada Label Makanan, yang antara lain menjelaskan:

a. Persetujuan pencantuman tulisan "halal" pada label makanan diberikan oleh Dirjen POM b. Produk makanan harus terdaftar pada Departemen Kesehatan RI

c. Persetujuan Pencantuman label "halal" diberikan setelah dilakukan pemeriksaan dan penilaian oleh Tim yang terdiri dari Departemen Kesehatan, Departemen Agama dan MUI

d. Hasil Penilaian Tim Penilai disampaikan kepada Komisi Fatwa MUI untuk dikeluarkan fatwanya, dan akhirnya diberikan Sertifikat Halal

e. Persetujuan Pencantuman "halal" diberikan oleh Dirjen POM berdasarkan sertifikat Halal yang berdasarkan MUI

f. Persetujuan berlaku selama 2 tahun sesuai dengan sertifikatnya

7. UU No. 8 tahun 1999 tentang Perlindungan Konsumen, yaitu :

Pasal 7 butir (b) :

Pelaku usaha berkewajiban memberikan informasi yang benar, jelas dan jujur mengenai kondisi dan jaminan barang dan/atau jasa.

Pasal 8 ayat 1 butir (h) :

Pelaku usaha dilarang memproduksi dan/atau memperdagangkan barang dan/atau jasa yang tidak mengikuti ketentuan berproduksi secara halal. Sebagaimana pernyataan "halal" yang dicantumkan dalam label.

8. PP No. 69 tahun 1999 tentang Label dan Iklan Pangan

a. Pasal 10

i. Setiap orang yang memproduksi atau memasukkan pangan yang dikemas ke dalam wilayah Indonesia untuk diperdagangkan dan menyatakan bahwa pangan 
tersebut "halal" bagi umat manusia, bertanggung jawab atas kebenaran pernyataan tersebut dan wajib mencantumkan keterangan atau tulisan halal pada label

ii. Pernyataan tentang "halal" sebagaimana dimaksud pada ayat (1) merupakan bagian yang tidak terpisahkan dari label

b. Pasal 11

i. Untuk mendukung kebenaran pernyataan "Halal" sebagaimana dimaksud dalam pasal 10 ayat (1), setiap orang yang memproduksi atau memasukkan pangan yang dikemas ke dalam wilayah Indonesia untuk diperdagangkan, wajib memeriksakan terlebih dahulu pangan tersebut pada lembaga pemeriksa yang telah diakreditasi sesuai dengan ketentuan peraturan perundangundangan yang berlaku.

ii. Pemeriksaan sebagaimana dimaksud pada ayat (1) dilaksanakan berdasarkan Pedoman dan Tata Cara yang ditetapkan oleh Menteri Agama, dengan memperhatikan pertimbangan dan saran lembaga keagamaan yang memiliki kompetensi di bidang tersebut.

\section{c. Pasal 59}

Pengawasan terhadap pelaksanaan ketentuan tentang label dan iklan dilaksanakan oleh Menteri Kesehatan

d. Pasal 60

i. Dalam melaksanakan ketentuan sebagaimana dimaksud dalam pasal 59, Menteri Kesehatan menunjuk pejabat untuk diserahi tugas pemeriksaan.

ii. Pejabat pemeriksa sebagaimana dimaksud dalam ayat (1) dipilih dan ditunjuk oleh Menteri Kesehatan berdasarkan keahlian tertentu yang dimiliki.

iii.Pejabat pemeriksa sebagaimana dimaksud dalam ayat (1) diangkat dan diberhentikan oleh Menteri Kesehatan.

9. Penjelasan PP No. 69 tahun 1999 pasal 11 ayat 1 menyatakan Pencantuman tulisan halal pada dasarnya bersifat sukarela.

Menurut Sampurno (2001), sanksi terhadap pelanggaran ketentuan pancantuman label dapat dikenakan :

1. Pidana penjara paling lama 3 (tiga) tahun dan atau denda paling banyak Rp. 360.000.000,- untuk pelanggaran terhadap UU No. 7 tahun 1996 pasal 34 ayat (1).

2. Tindak pidana penjara sampai 5 (lima) tahun atau denda sampai dua milyar rupiah untuk pelanggaran terhadap UU No. 8 tahun 1999 pasal 8 ayat (1) butir h.

3. Tindakan administratif terhadap pelanggaran PP No. 69 tahun 1999 yang meliputi :

- Peringatan secara tertulis

- Larangan untuk mengedarkan untuk sementara waktu dan atau perintah untuk menarik produk pangan dari peredaran. 


\section{KIAT MEMBELI PRODUK PANGAN DALAM KEMASAN}

Menurut Kusnandar (2012), beberapa kiat yang dapat membantu konsumen dalam memutuskan untuk membeli dan mengkonsumsi produk pangan dalam kemasan, antara lain :

\section{Teliti Informasi pada Kemasan}

Kemasan pangan memberikan informasi penting bagi konsumen. Informasi yang harus ada pada kemasan pangan adalah nama produk, merk dagang, nama dan alamat produsen, daftar bahan/ingredien/bahan tambahan pangan yang digunakan, berat atau isi bersih, dan waktu kadaluarsa. Ada juga informasi tambahan yang diberikan oleh produsen pada kemasan pangan, seperti komposisi nilai gizi (nutrition fact), kode produksi, cara penyimpanan atau penyajian, klaim kesehatan atau keunggulan produk, keterangan (logo) halal dan peringatan khusus.

Nama produk menjelaskan jenis produk dalam kemasan, misalnya snack kentang, mi instan, saus tomat, kecap asin, dsb. Merk dagang menjelaskan merk dari produk tersebut, seperti kecap merk XYZ, saus tomat merk KLM, dsb. Nama dan alamat produsen menjelaskan siapa yang memproduksi pangan tersebut dan dimana alamat pabriknya. Daftar bahan menjelaskan bahan apa saja yang digunakan untuk memproduksi pangan tersebut, termasuk juga dicantumkan bahan tanmbahan pangan yang digunakan (misalnya jenis pengawet, pewarna, pengental, dsb). Berat atau isi bersih menjelaskan berat atau volume produk per kemasan. Waktu kadaluarsa menjelaskan batas kelayakan produk pangan untuk dapat dikonsumsi sesuai dengan jaminan mutu dan keamanan pangan dari produsen.

\section{Periksa Nomor Registrasi pada Kemasan}

Bagaimana kita tahu apakah produk pangan dalam kemasan telah terdaftar secara resmi? Setiap produk pangan kemasan harus terdaftar dan telah melalui proses pemeriksaan kelayakannya terlebih oleh Badan POM. Setiap produk pangan akan memperoleh nomor registrasi yang harus dicantumkan pada kemasan pangan, yaitu nomor MD untuk produk pangan yang diproduksi di dalam negeri atau nomor ML (untuk produk pangan yang diimpor). Ada juga produk pangan yang mencantumkan nomor P-IRT pada kemasannya, yaitu umumnya untuk produk pangan yang diproduksi oleh industri kecil atau industri rumah tangga. Nomor P-IRT biasanya diberikan setelah produsen mengikuti pelatihan/ penyuluhan yang diselenggarakan oleh Dinas Kesehatan.

Nah, Anda harus memeriksa dahulu apakah pada kemasan pangan tersebut terdapat nomor MD, ML atau PIRT tersebut. Bila ada, maka produk pangan tersebut telah melalui proses pemeriksaan kelayakan dan terdaftar secara resmi di Badan POM (untuk MD dan ML) atau di Dinas Kesehatan (untuk P-IRT).

\section{Periksa masa kadaluarsa}

Seperti dijelaskan di atas, masa kadaluasa menjelaskan batas kelayakan produk pangan untuk dikonsumsi. Di luar masa kasa kaluarsa produk pangan sudah tidak memenuhi mutu dan keamanan seperti yang dijanjikan oleh produsen pada kemasan pangan. Jangan mengkonsumsi produk pangan yang sudah melebihi batas kadaluarsa atau produk yang menunjukkan tanda-tanda kerusakan, seperti kemasan yang rusak atau tidak normal (seperti kembung), 
perubahan warna, rasa, aroma, tekstur, berlendir, dsb.

\section{Periksa Keterangan (Logo) Halal}

Berdasarkan peraturan yang berlaku di Indonesia, pencantuman keterangan halal pada kemasan bersifat sukarela (voluntary). Namun demikian, bila logo halal dicantumkan pada kemasan, maka semua regulasi yang berlaku mengenai tatacara pencantuman logo halal pada kemasan harus dipenuhi oleh produsen, termasuk konsekuensi hukum yang harus ditanggung oleh produsen apabila logo halal yang dicantumkan palsu.

Izin pencantuman logo halal pada kemasan pangan menjadi kewenangan dari Badan POM, karena logo halal merupakan bagian dari kemasan pangan (harus menyatu dengan kemasan/tidak boleh ditempelkan dalam bentuk stiker). Badan POM akan mengeluarkan izin pencantuman logo halal apabila produk pangan sudah dinyatakan halal oleh MUI berdasarkan sertifikat halal.

Pencantuman logo halal tidak boleh bersifat self-claim, tetapi harus melalui proses pemeriksaan oleh lembaga yang berwenang (seperti LPPOM) dan jaminan produksi halal secara konsisten oleh produsen melalui implementasi sistem jaminan halal. Setiap produk yang telah melalui proses pemeriksaan dan mengimplementasikan sistem jaminan halal akan memperoleh sertifikat halal dari MUI. Sertifikat halal akan menjadi dasar bagi Badan POM untuk mengeluarkan izin pencantuman logo halal pada kemasan.

Bagaimana konsumen tahu logo halal yang tercantum pada kemasan adalah benar? Sekali lagi, cek apakah nomor pendaftaran (MD, ML, atau PIRT), kemudian apakah ada logo halalnya. Berdasarkan aturan pelabelan halal, logo halal harus mencantumkan nomor sertifikat dan bentuk logo resmi yang dikeluarkan MUI. Bila keduanya ada, Insya Allah logo halal yang tercantum dapat dipertanggungjawabkan.

\section{Hati-hati dengan Klaim Kesehatan pada Kemasan}

Setiap klaim kesehatan yang akan dicantumkan pada kemasan harus melewati proses evaluasi yang sangat ketat dan harus didasarkan pada bukti ilmiah yang dapat dipertanggungjawabkan. Tidak jarang untuk memutuskan izin suatu klaim kesehatan Badan POM harus melibatkan pakar berbagai bidang. Hal ini menunjukkan bahwa pencantuman klaim kesehatan harus hati-hati dan tidak menipu konsumen.

Oleh karena itu, konsumen harus berhati-hati mengenai kebenaran klaim kesehatan yang tercantum pada kemasan. Perlu diingat bahwa pangan atau makanan adalah bukan obat, sehingga klaim-klaim yang menunjukkan pangan sebagai obat tidak diizinkan. Oleh karena itu, hati-hati bila ada klaim pada kemasan pangan yang menyatakan dapat "menyembuhkan" suatu penyakit tertentu.

Bagaimana kita tahu suatu klaim kesehatan benar? Lagi-lagi cek apakah pada kemasan produk tersebut ada nomor registrasi (MD atau ML), karena pernyataan klaim kesehatan juga harus menyatu dengan kemasan pangan. Dengan demikian, klaim kesehatan untuk produk yang belum terdaftar tidak dapat dipertanggungjawabkan. 


\section{DAFTAR PUSTAKA}

, 1996. Undang-Undang No

7: tentang pangan

An-nabani, T. 2001. Peraturan Hidup Dalam Islam. Pustaka Tariqul Izzah, Jakarta

Apriyantono, A. 2005. Masalah Halal : Kaitan antara Syar'i, Teknologi dan Sertifikasi. Penerbit PT Kiblat Buku Utama. Bandung

Girindra. 2002. Kebijakan LPPOM MUI dalam Sertifikasi Halal, Produk Impor Serta Lembaga Sertifikasi Internasional. Makalah pada Pelatihan Auditor Halal Internal
Perusahaan, 16 Oktober 2002, Jakarta.

Kusnandar, Feri. 2012. Kiat Memilih Produk Pangan Kemasan yang Aman dan Halal. http:// ilmudanteknologipangan.com/. Diunduh pada Tanggal 15 April 2013.

Qardhawi, Y. 2000. Halal dan Haram dalam Islam. Robbani Press, Jakarta

Sampurno. 2001. Label Pangan dan Label Peran: Dalam Prespektif Peran, Tugas dan Tanggung Jawab BPOM. Badan POM, Jakarta 